Groothuis, P.A., Groothuis, J.D., and Whitehead, J.C. (2007) The Willingness to Pay to Remove Billboards and Improve Scenic Amenities, Journal of Environmental Management, 85(4): 1094-1100 (Dec 2007). Published by Elsevier (ISSN: 0301-4797). doi:10.1016/j.jenvman.2006.11.007

\title{
The willingness to pay to remove billboards and improve scenic amenities
}

Peter A. Groothuis, Jana D. Groothuis, and John C. Whitehead

\begin{abstract}
We use the contingent valuation method to measure the amount citizens are willing to pay to improve scenic mountain-view amenities through the removal of billboards. Our approach addresses both the perceived property rights as well as the perceptions of the status quo in the southern Appalachian Mountains. We find that individuals who retire to the mountains have different preferences for land use and mountain views than individuals who have ancestors who lived in Watauga County. In the aggregate, we find that citizens are willing to pay almost onehalf million dollars to remove billboards from Watauga County roadsides. This study provides insights to the debate surrounding land use along public roads.
\end{abstract}




\section{INTRODUCTION}

The debate on land use has been around for years. Debate points include, should counties develop zoning ordinances? Should states designate roads as scenic byways? Should billboards be removed? Should cell towers be built? Should the county regulate the number of abandoned cars? In Watauga County, North Carolina, grassroots organizations have formed to monitor land use. Partially through the efforts of one such group, the Committee of 100 , a section of the new Route 421 was designated a scenic byway where no billboards were allowed to be built. Another group, identified with the other side of the debate printed "No Zoning in Watauga County" bumper stickers. This statement was also placed on billboards along the old section of Route 421.

The debate over the removal of billboards does not exist only in the southern Appalachian Mountains. In Poland, a study found that travelers along highways are willing to pay to remove billboards and improve the rural views (Szoege et al., 2005). In the United States, since the highway beautification act passed in 1965, municipalities have passed laws for the removal of billboards for aesthetic reasons. Some have suggested that billboard bans infringe upon freedom of speech but, in Metromedia Inc. vs. San Diego, the Supreme Court ruled that a city may regulate aesthetics under its police power and generally ban outdoor signs for aesthetic reasons alone (Bond, 1990). In North Carolina, a new state ordinance requires that landowners must be compensated for the lost revenue if a municipality bans billboards. This explicitly assigns the property rights to the landowner.

We conducted a contingent valuation method (CVM) survey to assess whether citizens are willing to pay to remove billboards for aesthetic reasons. In the next section of this paper, we discuss the survey methods. In Section 3, we provide some insights in to how people perceive property rights and mountain-view amenities. In Section 4 we report the results of the willingness to pay (WTP) for the removal of billboards. In Section 5, we provide estimates of WTP for different subgroups of the population of Watauga County. We also provide an aggregate estimate of WTP. In Section 6 we conclude.

\section{THE SURVEY}

To help understand the value of mountain views and land use, we developed a contingent valuation method survey to elicit the WTP for changes in the county's view-shed amenities for the removal of billboards (Mitchell and Carson, 1989). The survey was mailed in the spring of 2005 to a random sample of 1200 Watauga County residents. We used a primary mailing, a post card reminder and a second mailing to all non-respondents of the first mailing. In the end, we had 901 useable addresses and 389 responses giving us a response rate of $43 \%$. We find that the average age of our respondent was 56.5 years, while the average age for county residents over 20 was 43.5 (Table 1). We find that the average income of survey respondents was $\$ 60,470$. The average income in Watauga County from the 2000 census was $\$ 50,300$ in 2005 dollars. The average education for the respondents was 15 years while for the county it was 14 years. The percentage of male survey respondents was $60 \%$ where the county average 
is $50 \%$ male. The sample of respondents is more likely to be male, older, more educated and have higher household income than the population.

Table 1

Means of variables

\begin{tabular}{ll}
\hline Variable & Mean (standard deviation) \\
\hline Age (years) & $56.5(15.8)$ \\
Income $^{\mathrm{a}}$ & $\$ 60,470(33,900)$ \\
Education (years) & $14.97(3.8)$ \\
Male & $0.60(0.49)$ \\
Drive with view & $0.81(0.39)$ \\
Home with view & $0.59(0.58)$ \\
Ancestor from Watauga & $0.33(0.46)$ \\
Retire to Watauga & $0.11(0.31)$ \\
Billboards-useful information & $0.15(0.36)$ \\
Bill boards-harmful & $0.51(0.50)$ \\
\hline
\end{tabular}

$n=355$.

${ }^{a}$ We impute 18 missing wage values using a wage equation (Whitehead, 1994).

Eighty-one percent of the respondents report they have a daily drive with a scenic view that could be altered by cell towers, billboards or electrical generation windmills; while $59 \%$ report their residence has a scenic view that could be altered. We also find that $11 \%$ of the respondents moved to Watauga County after they retired. Lastly we find that $33 \%$ of respondents report having ancestors who lived in Watauga County.

\section{OPINIONS ON MOUNTAIN VIEWS}

We next consider opinions about land use in Watauga County (Table 2). We find that $67 \%$ either agree or strongly agree that land-use zoning should be used in Watauga County while $42 \%$ either agree or strongly agree that land owners should use their land any way they want. Ninety-seven percent either agree or strongly agree that mountain views are an important part of the quality of life and $92 \%$ agree or strongly agree that ridge laws that prevent buildings on the top of mountains are important. Twenty-five percent agree or strongly agree that Route 421 should not have been designated a scenic byway while only $10 \%$ agree or strongly agree that abandoned cars do not harm the landscape. Lastly, we find that $60 \%$ agree or strongly agree that electrical generation windmills should be allowed in Watauga County and $51 \%$ agree or strongly agree that cell towers harm the mountain view-shed. 
Table 2

Opinions about land use

\begin{tabular}{lcrrr}
\hline & Strongly agree & Agree & Disagree & Strongly disagree \\
\hline Should have Zoning & $43.4 \%$ & $23.3 \%$ & $11.1 \%$ & $13.4 \%$ \\
Cell tower harmful to views & $17.0 \%$ & $34.2 \%$ & $30.1 \%$ & $9.8 \%$ \\
Landowner should use land anyway they want & $21.6 \%$ & $20.3 \%$ & $33.7 \%$ & $19.8 \%$ \\
Route 421 should not be Scenic byway & $10.5 \%$ & $14.4 \%$ & $23.4 \%$ & $37.8 \%$ \\
Ridge law is important & $71.2 \%$ & $21.6 \%$ & $3.3 \%$ & $1.3 \%$ \\
Mountain view important for quality of life & $70.2 \%$ & $26.5 \%$ & $1.3 \%$ & $0.3 \%$ \\
Electrical windmills should be allowed & $19.0 \%$ & $40.6 \%$ & $14.4 \%$ & $8.2 \%$ \\
Abandoned cars do not harm the landscape & $3.6 \%$ & $5.9 \%$ & $20.8 \%$ & $66.8 \%$ \\
\hline
\end{tabular}

Sample size $=355$.

To further explore people's opinions about land use, we analyze these attitudes using ordered logistic regression (Table 3). We find that when a respondent reports that they own a home with a view, it increases the likelihood that they are of the opinion that ridge laws are important. These same individuals also are more likely to find that cell towers harm the mountain landscape and that mountain views are important for quality of life in Watauga County. We also find that when respondents report they have a daily drive with a mountain view that can be altered they are more likely to be in favor of zoning ordinances and ridge laws. These respondents are also less likely to believe land owners should be able to use their land any way they want. In addition, respondents who have daily drives with views that can be altered report that cell towers and abandoned cars damage mountain views and that mountain views are important to the quality of life in Watauga County. They also are more likely to answer that Route 421 should be designated as a scenic byway and that electrical generation windmills should not be allowed in Watauga County. 
Table 3

Determinants of opinions of land use: Ordered-Logit

\begin{tabular}{|c|c|c|c|c|c|c|c|c|}
\hline & $\begin{array}{l}\text { Should have } \\
\text { Zoning }\end{array}$ & $\begin{array}{l}\text { Cell tower } \\
\text { harmful to } \\
\text { views }\end{array}$ & $\begin{array}{l}\text { Land owner } \\
\text { should use } \\
\text { land anyway } \\
\text { they want }\end{array}$ & $\begin{array}{l}\text { Route } 421 \\
\text { should not be } \\
\text { Scenic byway }\end{array}$ & $\begin{array}{l}\text { Ridge law is } \\
\text { important }\end{array}$ & $\begin{array}{l}\text { Mt view } \\
\text { important for } \\
\text { quality of life }\end{array}$ & $\begin{array}{l}\text { Electrical } \\
\text { windmill } \\
\text { should be } \\
\text { allowed }\end{array}$ & $\begin{array}{l}\text { Abandoned } \\
\text { cars do not } \\
\text { harm the } \\
\text { landscape }\end{array}$ \\
\hline Intercept 1 & $\begin{array}{l}-2.80^{* *} \\
(14.43)\end{array}$ & $\begin{array}{l}-3.55^{* *} \\
(27.98)\end{array}$ & $\begin{array}{c}-1.39^{* *} \\
(2.10)\end{array}$ & $\begin{array}{c}1.21^{*} \\
(3.53)\end{array}$ & $\begin{array}{c}-0.58 \\
(0.52)\end{array}$ & $\begin{array}{c}0.04 \\
(0.00)\end{array}$ & $\begin{array}{c}-0.08 \\
(0.02)\end{array}$ & $\begin{array}{c}-0.93 \\
(1.42)\end{array}$ \\
\hline Intercept 2 & $\begin{array}{c}-1.34^{* *} \\
(3.42)\end{array}$ & $\begin{array}{c}-1.63^{* *} \\
(6.26)\end{array}$ & $\begin{array}{l}1.39^{* *} \\
(12.10)\end{array}$ & $\begin{array}{l}2.617^{*} \\
(15.95)\end{array}$ & $\begin{array}{r}1.78^{*} \\
(4.59)\end{array}$ & $\begin{array}{r}3.32^{*} \\
(15.66)\end{array}$ & $\begin{array}{l}2.18 \\
(9.45)\end{array}$ & $\begin{array}{c}0.24 \\
(0.11)\end{array}$ \\
\hline Intercept 3 & $\begin{array}{r}-0.32 \\
(0.19)\end{array}$ & $\begin{array}{c}0.50 \\
(0.60)\end{array}$ & $\begin{array}{l}3.34^{* *} \\
(21.03)\end{array}$ & $\begin{array}{c}4.56^{* *} \\
(44.40)\end{array}$ & $\begin{array}{l}2.91^{* *} \\
(9.93)\end{array}$ & $\begin{array}{c}5.16^{* *} \\
(16.81)\end{array}$ & $\begin{array}{c}3.40^{* *} \\
(21.84)\end{array}$ & $\begin{array}{l}1.88^{* *} \\
(6.30)\end{array}$ \\
\hline Income & $\begin{array}{c}0.004 \\
(0.54)\end{array}$ & $\begin{array}{l}-.006^{* *} \\
(3.04)\end{array}$ & $\begin{array}{c}-0.005 \\
(0.17)\end{array}$ & $\begin{array}{r}0.005 \\
(0.02)\end{array}$ & $\begin{array}{c}0.003 \\
(0.38)\end{array}$ & $\begin{array}{l}-.003 \\
(0.72)\end{array}$ & $\begin{array}{l}-0.007^{* *} \\
(3.30)\end{array}$ & $\begin{array}{c}-0.01^{* *} \\
(5.13)\end{array}$ \\
\hline Home view & $\begin{array}{c}0.35 \\
(2.12)\end{array}$ & $\begin{array}{c}0.86^{* *} \\
(14.37)\end{array}$ & $\begin{array}{c}0.28 \\
(1.26)\end{array}$ & $\begin{array}{c}-0.25 \\
(1.34)\end{array}$ & $\begin{array}{l}0.63^{* *} \\
(5.07)\end{array}$ & $\begin{array}{l}0.56^{* *} \\
(4.18)\end{array}$ & $\begin{array}{r}-0.159 \\
(0.44)\end{array}$ & $\begin{array}{l}-.0 .32 \\
(1.47)\end{array}$ \\
\hline Drive view & $\begin{array}{c}1.13^{* *} \\
(14.08)\end{array}$ & $\begin{array}{l}0.79^{* *} \\
(7.42)\end{array}$ & $\begin{array}{l}1.16^{* *} \\
(3.77)\end{array}$ & $\begin{array}{l}-1.18^{* *} \\
(15.27)\end{array}$ & $\begin{array}{l}0.66^{* *} \\
(3.74)\end{array}$ & $\begin{array}{l}0.61^{* * *} \\
(3.18)\end{array}$ & $\begin{array}{l}-0.592^{* *} \\
(3.79)\end{array}$ & $\begin{array}{l}-1.19^{* *} \\
(14.62)\end{array}$ \\
\hline Ancestor & $\begin{array}{l}-1.40^{* *} \\
(30.96)\end{array}$ & $\begin{array}{c}-0.67^{*} \\
(8.34)\end{array}$ & $\begin{array}{c}-1.20^{* *} \\
(4.82)\end{array}$ & $\begin{array}{c}1.26^{* *} \\
(28.23)\end{array}$ & $\begin{array}{l}-0.90^{* *} \\
(10.36)\end{array}$ & $\begin{array}{l}-1.11^{* *} \\
(16.78)\end{array}$ & $\begin{array}{c}-0.498 \\
(1.92)\end{array}$ & $\begin{array}{l}0.72^{* *} \\
(7.84)\end{array}$ \\
\hline Retire & $\begin{array}{r}-0.04 \\
(0.00)\end{array}$ & $\begin{array}{c}0.35 \\
(1.02)\end{array}$ & $\begin{array}{r}-0.18 \\
(0.37)\end{array}$ & $\begin{array}{r}-0.42 \\
(1.28)\end{array}$ & $\begin{array}{c}-0.61 \\
(1.70)\end{array}$ & $\begin{array}{r}-0.12 \\
(0.07)\end{array}$ & $\begin{array}{r}-0.50 \\
(1.92)\end{array}$ & $\begin{array}{c}0.32 \\
(0.55)\end{array}$ \\
\hline Age & $\begin{array}{l}0.019^{* *} \\
(5.49)\end{array}$ & $\begin{array}{l}0.012^{*} \\
(2.90)\end{array}$ & $\begin{array}{l}0.017^{*} \\
(2.48)\end{array}$ & $\begin{array}{r}-0.011 \\
(2.48)\end{array}$ & $\begin{array}{l}0.018^{*} \\
(3.69)\end{array}$ & $\begin{array}{r}0.000 \\
(0.00)\end{array}$ & $\begin{array}{c}0.095 \\
(1.56)\end{array}$ & $\begin{array}{l}-0.028^{* *} \\
(11.71)\end{array}$ \\
\hline Education & $\begin{array}{r}0.058 \\
(2.49)\end{array}$ & $\begin{array}{r}0.042 \\
(1.98)\end{array}$ & $\begin{array}{l}0.10^{* *} \\
(13.78)\end{array}$ & $\begin{array}{l}-0.11^{* *} \\
(13.09)\end{array}$ & $\begin{array}{r}0.001 \\
(0.02)\end{array}$ & $\begin{array}{c}0.05 \\
(0.04)\end{array}$ & $\begin{array}{c}0.05^{* *} \\
(61.25)\end{array}$ & $\begin{array}{c}0.01 \\
(0.08)\end{array}$ \\
\hline Model $\chi^{2}$ & 89.04 & 57.47 & 104.13 & 48.70 & 32.73 & 39.36 & 15.92 & 51.47 \\
\hline Sample size & 323 & 339 & 329 & 320 & 345 & 349 & 306 & 351 \\
\hline
\end{tabular}

Wald $\chi^{2}$ statistic reported.

**Significant at the $p=0.01$.

*Significant at the $p=0.05$.

${ }^{\text {a }}$ The don't know response category was deleted form the ordered logistic equations.

Individuals with ancestors from Watauga County are more likely to agree that electrical generation windmills should not be allowed in the county. These same individuals are also less likely, however, to agree that zoning and ridge laws should be used, and that Route 421 should have been designated a scenic byway. They are also less likely to agree that cell towers or abandoned cars harm mountain landscapes and that mountain views are important to the quality of life in their county. Lastly, residents with ancestors in Watauga County are more likely to agree that land owners should be able to use their land as they choose.

Individuals who have retired to Watauga County are less likely to agree that land owners should use their land any way they want. Respondents with more education are also less likely to agree that land owners should use their land any way they see fit and more likely to agree that Route 421 should have been designated a scenic byway. Lastly, as age of the respondent increases they are more likely to agree that zoning is important and less likely to agree that land owners should use land any way they want. The importance of ridge laws also increases with age.

In Table 4, we summarize the opinions about the usefulness and impact on mountain views of billboards. We find that $46 \%$ of respondents report that billboards provide somewhat useful information and $42 \%$ use billboards to make decisions on where to shop and eat when they visit other locations. Yet around $80 \%$ find that billboards are somewhat harmful or very harmful to the mountain views of Watauga County. 
Table 4

Opinions about billboards

\begin{tabular}{|c|c|c|c|c|c|}
\hline & $1-$ Not at all useful & 2 & 3 & 4 & 5-Very useful \\
\hline \multirow[t]{2}{*}{ Provide useful information } & $14.9 \%$ & $22.5 \%$ & $46.3 \%$ & $7.8 \%$ & $8.3 \%$ \\
\hline & $1-$ Not at all harmful & 2 & 3 & 5 & 5-Very harmful \\
\hline \multirow[t]{2}{*}{ Harmful to Mt Views } & $9.4 \%$ & $8.9 \%$ & $32.5 \%$ & $18.3 \%$ & $30.9 \%$ \\
\hline & 1-Never & 2 & 3 & 4 & 5-All the time \\
\hline Use to make decisions & $27.2 \%$ & $16.2 \%$ & $42.4 \%$ & $6.8 \%$ & $7.3 \%$ \\
\hline
\end{tabular}

Sample size $=355$.

We find a negative correlation, $r=-0.61$, between those who state that billboards provide useful information and those who find billboards harmful to mountain views. We also find a positive correlation, $r=0.65$, between those who report that billboards provide useful information to tourists and residents and those who report using billboards to make decisions when they travel to other locations.

These results suggest that respondents tend to find that billboards are somewhat useful. They also feel that billboards harm mountain-view amenities, suggesting that tradeoffs need to be made. In the next section, we analyze the CVM questions on the WTP for changes in mountainview amenities.

\section{WILLINGNESS TO PAY FOR BILLBOARD REMOVAL}

\subsection{Theory}

Consider a resident's who receives utility from both a consumption good, $z$, and a scenic view amenity, $q$, where $q$ represents quality of the scenic amenity that can be affected by the presence of billboards. A resident maximizes her utility, $u(q, z)$, subject to a budget constraint $y=p z$ where the price of $z$ is normalized to one. Solving for the indirect utility function yields $v(q$, $y)$. The willingness-to-pay, WTP, for the scenic view amenity is implicitly defined at the payment that equates indirect utility with different quality conditions, $v\left(q^{0}, y\right)=v\left(q^{\prime}, y\right.$-WTP), where $q^{0}$ is the current quality, $q^{\prime}$ is the improved quality.

In our case, the WTP question for billboard removal follows a dichotomous choice framework. The variable Yes is a qualitative variable equal to one if the respondents answered "for" to the question:

The State of North Carolina, through the Highway Beautification Act, has suggested removing billboards along state highways. The federal government has mandated that when billboards are removed land owners need to be compensated for lost income from billboards. Suppose Watauga County proposes the removal of all billboards to improve mountain views. Suppose that to remove billboards county residents would pay a one time payment of $\$ A$ per household in higher county taxes. The money would be used to compensate land owners for lost income they would have received from the billboards. Suppose that this proposal to approve the tax and remove billboards will be on the next 
election ballot. Remember, if the proposal passes you would make a one-time payment of \$A in higher taxes and you would have \$A less to spend on other things. Also remember that billboards would no longer be allowed on Watauga county highways.

\$A is a randomly assigned bid variable. Respondents were given three alternative answers: for, against and don't know. One problem that arises when coding dichotomous choice CVM questions is what should be done with "don't know" responses. We follow the conservative approach and code all "don't know" responses as "no" responses (Caudill and Groothuis, 2005). This is our Yes 1 variable.

Another problem that arises with CVM surveys is hypothetical bias (Whitehead and Cherry, forthcoming). Hypothetical bias exists if respondents are more likely to say that they would pay a hypothetical sum of money than they would actually pay if placed in the real situation. Since economic values are based on actual behavior, hypothetical bias leads to economic values that are too high. One method that is used to mitigate hypothetical bias is the certainty rating. For those respondents who say that they are willing to pay we ask: "On a scale of 1-10 where 1 is 'not sure at all' and 10 is 'definitely sure', how sure are you that you would make the one-time donation of the tax amount?" Following Whitehead and Cherry's (forthcoming) recommendation only respondents who answer greater than 7 are coded as a yes response. We identify this variable as Yes 2. In Table 5, we report the proportions of Yes 1 and Yes 2 at each cost level. The yes responses follow the expected pattern; as the bid rises the proportion of yes responses fall.

\begin{tabular}{|c|c|c|c|c|c|c|}
\hline & & $\$ 10$ & $\$ 25$ & $\$ 100$ & $\$ 250$ & $\$ 500$ \\
\hline \multirow{4}{*}{ Yes $1 \mathrm{w} / \mathrm{o}$ hypothetical bias correction } & Yes & 41 & 42 & 30 & 31 & 14 \\
\hline & Total & 64 & 80 & 61 & 85 & 65 \\
\hline & Percent & $64 \%$ & $52 \%$ & $49 \%$ & $36 \%$ & $22 \%$ \\
\hline & Yes & 39 & 39 & 28 & 25 & 8 \\
\hline \multirow[t]{2}{*}{ Yes 2 with hypothetical bias correction } & Total & 64 & 80 & 61 & 85 & 65 \\
\hline & Percent & $61 \%$ & $48 \%$ & $45 \%$ & $29 \%$ & $12 \%$ \\
\hline
\end{tabular}

Sample size $=355$.

We estimate three logistic model specifications for each of our "yes" variables:

(1)

$P($ Yes $)=1 /\left(1+\exp \left[\beta_{0}+\beta_{1} \ln (A)+\beta_{2}\right.\right.$ Income $\left.]\right)$,

$P($ Yes $)=1 /\left(1+\exp \left[\beta_{0}+\beta_{1} \ln (\mathrm{A})+\beta_{2}\right.\right.$ Income $+\beta_{3}$ Education $+\beta_{4}$ Ancestor $+\beta_{5}$ Homeview $+\beta_{6}$ Driveview $+\beta_{7}$ Retire]), 
(3)

$P($ Yes $)=1 /\left(1+\exp \left[\beta_{0}+\beta_{1} \ln (A)+\beta_{2}\right.\right.$ Income $+\beta_{3}$ Education $+\beta_{4}$ Zone $+\beta_{5}$ Billboard-useful $+\beta_{6}$ Billboardharmful]),

where $P($ Yes $)$ is the probability of a "yes" response.

\subsection{Results}

First considering all, we find that the tax payment negatively affects the likelihood of a yes response indicating that respondents are rational towards cost (Table 6). In model one without the hypothetical bias correction, income positively effects the likelihood of a yes response indicating that the improvement of mountain views from billboard removal is a normal good. Note that when the log of the cost amount is used in the specification the median WTP is estimated and the mean is undefined (Haab and McConnell, 2002). The median is lower than the mean estimate thus providing a conservative estimate of the benefits of removing billboards. Following the method described by Cameron (1991), we estimate that the median WTP for billboard removal is $\$ 48$ per household with a 95\% confidence interval of \$19 to \$77. [1]

Table 6

Determinants of willingness to pay for billboard removal

\begin{tabular}{|c|c|c|c|c|c|c|}
\hline \multirow[t]{2}{*}{ Variable } & \multicolumn{3}{|l|}{ Yes 1} & \multicolumn{3}{|l|}{ Yes 2} \\
\hline & Model 1 & Model 2 & Model 3 & Model 1 & Model 2 & Model 3 \\
\hline Intercept & $\begin{array}{c}1.08 \\
(2.68)\end{array}$ & $\begin{array}{r}-0.83 \\
(1.12)\end{array}$ & $\begin{array}{r}-1.02 \\
(1.40)\end{array}$ & $\begin{array}{c}1.18 \\
(2.85)\end{array}$ & $\begin{array}{c}-1.46 \\
(3.73)\end{array}$ & $\begin{array}{c}-1.31^{*} \\
(1.72)\end{array}$ \\
\hline $\log \$ \mathrm{~A}$ & $\begin{array}{c}-0.388^{*} \\
(4.80)\end{array}$ & $\begin{array}{c}-0.440^{*} \\
(4.82)\end{array}$ & $\begin{array}{c}-0.465^{*} \\
(4.44)\end{array}$ & $\begin{array}{c}-0.493^{*} \\
(5.81)\end{array}$ & $\begin{array}{c}1.585^{*} \\
(5.95)\end{array}$ & $\begin{array}{c}-0.648^{*} \\
(5.58)\end{array}$ \\
\hline Income & $\begin{array}{c}0.007^{*} \\
(2.03)\end{array}$ & $\begin{array}{l}-.0004 \\
(0.12)\end{array}$ & $\begin{array}{l}-.0022 \\
(0.63)\end{array}$ & $\begin{array}{c}0.009^{*} \\
(2.43)\end{array}$ & $\begin{array}{l}-.0004 \\
(0.91)\end{array}$ & $\begin{array}{l}-.0007 \\
(0.87)\end{array}$ \\
\hline Education & & $\begin{array}{c}0.10^{*} \\
(2.66)\end{array}$ & $\begin{array}{c}0.09^{*} \\
(2.31)\end{array}$ & & $\begin{array}{l}0.13^{*} \\
(3.18)\end{array}$ & $\begin{array}{l}0.12^{*} \\
(2.76)\end{array}$ \\
\hline Drive with view & & $\begin{array}{c}1.17^{*} \\
(3.01)\end{array}$ & & & $\begin{array}{l}1.61^{*} \\
(3.50)\end{array}$ & \\
\hline Home with view & & $\begin{array}{c}0.49^{*} \\
(1.80)\end{array}$ & & & $\begin{array}{l}0.61^{*} \\
(2.12)\end{array}$ & \\
\hline Ancestor in Watauga & & $\begin{array}{c}-1.21^{*} \\
(4.06)\end{array}$ & & & $\begin{array}{c}-1.30^{*} \\
(3.97)\end{array}$ & \\
\hline Retired to Watauga & & $\begin{array}{c}1.23^{*} \\
(2.67)\end{array}$ & & & $\begin{array}{c}0.98^{*} \\
(2.30)\end{array}$ & \\
\hline Zoning & & & $\begin{array}{c}1.18^{*} \\
(3.95)\end{array}$ & & & $\begin{array}{l}01.36^{*} \\
(4.29)\end{array}$ \\
\hline Bill board-useful & & & $\begin{array}{c}-1.20^{*} \\
(2.24)\end{array}$ & & & $\begin{array}{r}-1.03^{*} \\
(1.72)\end{array}$ \\
\hline Bill board-harmful & & & $\begin{array}{c}2.14^{*} \\
(7.17)\end{array}$ & & & $\begin{array}{c}2.31^{*} \\
(6.91)\end{array}$ \\
\hline Model $\chi^{2}$ & $27.81^{*}$ & $96.92^{*}$ & $168.36^{*}$ & $41.63^{*}$ & $117.89^{*}$ & $185.51^{*}$ \\
\hline Willingness to pay & $\begin{array}{l}\$ 48 \\
(\$ 19, \$ 77)\end{array}$ & $\begin{array}{l}\$ 41 \\
(\$ 16, \$ 67)\end{array}$ & $\begin{array}{l}\$ 40 \\
(\$ 12, \$ 67)\end{array}$ & $\begin{array}{l}\$ 31 \\
(\$ 14, \$ 48)\end{array}$ & $\begin{array}{l}\$ 25 \\
(\$ 10, \$ 39)\end{array}$ & $\begin{array}{l}\$ 25 \\
(\$ 10 \$ 40)\end{array}$ \\
\hline
\end{tabular}

*Significant at the $p=0.05$ level.

Sample size $=355$. 
In model 2 we find that the coefficient on education is positive and significant. In addition those who report a home with a view and a drive with a view that can be altered are more likely to answer "yes" to the removal of billboards. We also find that those who moved to Watauga County after they retire are more likely to answer "yes". Those who have ancestors in Watauga County are less likely to answer "yes" to the WTP question. We explore these differences in the next section. The median WTP in this specification is \$41 per household with a 95\% confidence interval of $\$ 16$ to $\$ 67$ (Table 6).

In model 3, we focus on three dummy variables measuring preferences about billboards. The first dummy variable, Zoning, is coded as one if the respondent is in favor of zoning in the county and zero otherwise. Individuals who are in favor of zoning are more likely to say "yes" to the removal of billboards. The second dummy variable, Billboard-useful, is equal to one if the respondent found that billboards provide very useful information (i.e., answered either 4 or 5 on the Likert scale). The third dummy variable, Billboard-harmful is equal to one if the respondent felt that billboards are very harmful to mountain views answering either 4 or 5 on the Likert scale. The coefficients on both are as expected. Individuals who state that billboards do not provide useful information and those who state that billboards are harmful are more likely to say "yes" to the proposal. The point estimate of WTP in this specification is $\$ 40$ with a 95\% confidence interval of $\$ 12$ to $\$ 67$.

In the second set of models, we use the Yes 2 measure that corrects for hypothetical bias. The results mirror the results from the first set of models in terms of sign and significance. When the median WTP estimates are corrected for hypothetical bias they fall to $\$ 31$ for the first specification with a $95 \%$ confidence interval of $\$ 14$ to $\$ 48$. In the second two specifications we find that both have a median WTP estimate of $\$ 25$ per household with $95 \%$ confidence intervals of $\$ 10$ to $\$ 40$.

\section{DEMOGRAPHIC DIFFERENCE AND AGGREGATE WILLINGNESS TO PAY}

The debate over land use in the mountains involves diverse demographic groups with heterogeneous preferences. Using the information from the logit specifications above, we can focus on each subgroup and calculate their WTP by evaluating each dummy variable at either one, indicating the respondent has the characteristic, and zero indicating the respondent does not have the characteristic. One subgroup is individuals who have retired to the mountains. We find that their median WTP is $\$ 495$ while those who did not retire to the mountains have a WTP of $\$ 30$. In addition, we find that individuals who have ancestors in the county have a WTP of only $\$ 6$ while those who do not have ancestors in the county have a WTP of $\$ 100$. These results support the conjecture that newcomers' preferences are different than natives. It also suggests why the debate becomes contentious with one sub group finding the removal of billboards unimportant and another finding that it is a major concern.

Overall, however, our results indicate that the majority of households perceive that the mountain-view amenity would be improved through the removal of billboards with the sample being willing to pay a positive amount from $\$ 25$ to $\$ 48$. To estimate the aggregate WTP to 
remove billboards from all roads in Watauga County, we use the most conservative WTP estimate. Using the 2000 census we find that there are 18,540 households in Watauga County giving an aggregate WTP of about $\$ 463,500$ dollars. This estimate can be thought of as the amount that would be approved in a referendum election-reflecting the preferences of a median voter. Once again, it can also be thought of as a conservative benefit estimate because the mean WTP, which is more appropriate for benefit-cost analysis, is above the median. In addition the affect of billboards on the scenic amenity influences non-residents as well as residents. The value of the scenic amenity to non-residents who visit the mountains can not directly be measured in the WTP further suggesting that the WTP is a conservative estimate.

To help understand the meaning of the aggregate WTP, note that the county has three highways that have been designated scenic byways: Route 194, Route 421 (called the Merle and Doc Waston scenic byway) and the Blue Ridge Parkway. No billboards are allowed on these three roads. In addition, the county has three corridors that all pass through Boone: Highway 105, Route 321, and Route 421 West. Along these roads there are a total of 165 billboards. Our results suggest that households are willing to compensate land owners \$2810 per billboard to remove billboards and improve mountain views.

\section{CONCLUSIONS}

We find that the majority of individuals value mountain views and desire some regulation to protect the aesthetic values of mountain views. For example the majority are in favor of ridge laws that prevent mountain top building as well as zoning restrictions. We also find that while individuals find that billboards provide useful information they also find billboards harmful to mountain views. Our results show that individuals who buy homes with views that can be altered by billboards, electrical generation wind mills, or cell-phone towers, and those who retire to Watauga County have different preferences than individuals who have ancestors in the county when it comes to changes in the view shed. A conservative total benefit of removing billboards from Watauga county roads is $\$ 463,500$ or $\$ 2810$ per billboard. If landowners are willing to accept this offer it would be efficient to remove billboards from Watauga County, North Carolina. 


\section{APPENDIX 1.}

We should have land zoning in Watauga County.

Cell towers harm the mountain landscape in Watauga

County.

Landowners in Watauga County should be able to use their land any way they want.

The new Route 421 from the Blue Ridge Parkway to Boone should not have been designated as a scenic byway.

The ridge law preventing tall buildings on top of mountains is important for Watauga County. Mountain views are an important part of the quality of life in Watauga County.

Electrical generation wind mills should be allowed in Watauga County.

Abandoned cars do not harm the landscape of Watauga County.
$\mathrm{SA}$

SA

SA

SA

SA

SA

SA

SA

A

D

SD

DK
D

D

D

D

SD

SD

SD

SD

DK
DK

DK

DK

\section{BILLBOARD QUESTIONS}

B1. Do you feel billboards provide useful information to tourist and residents?

$1 \quad 2 \quad 3 \quad 4$

(Not At All Useful) (Somewhat Useful)

B2. Do you feel that billboards are harmful to the mountain views?
2

(Not At All Harmful)
3

(Somewhat Harmful) 


\section{NOTES}

1. Given the fact that some respondents indicated that billboards are useful, there exists is a possibility of a negative WTP (Haab and McConnell, 1997). We have calculated the WTP using the standard Cameron approach with a linear bid that allows for negative WTP but find the mean WTP to be higher than the median WTP when WTP is constrained to be positive.

\section{REFERENCES}

Bond, R.D., 1990. Making sense of billboard law: justifying prohibitions and exemptions. Michigan Law Review 88 (8).

Cameron, TA., 1991. Interval estimates of non-market resource values from referendum contingent valuation surveys. Land Economics 67, 413-421.

Caudill, S., Groothuis, P.A., 2005. Modeling hidden alternatives in random utility models. Land Economics 81 (3), 445-454.

Haab, T.C., McConnell, K.E., 1997. Referendum models and negative willingness to pay: alternative solutions. Journal of Environmental Economics and Management 32 (2), 251-270.

Haab, T.C., McConnell, K.E., 2002. Valuing Environmental and Natural Resources: the Econometrics of Non-Market Valuation. Edward Elgar, Northampton, MA.

Szoege, H.M., Agnieszka, S., W"adys"aw, M.S., 2005. Valuing protection of the rural landscape in the public opinion. Electronic Journal of Agricultural Universites 8 (2).

Mitchell, R.C., Carson, R.T., 1989. Valuing Public Goods: the Contingent Valuation Method. Resources for the Future, Washington, DC.

Whitehead, J.C., 1994. Item nonresponse bias in contingent valuation: should cv researchers impute values for missing independent variables? Journal of Leisure Research 26, 296-303.

Whitehead, J.C., Cherry, T.L., Mitigating the hypothetical bias of willingness to pay: a comparison of ex-ante and ex-post approaches. Resource and Energy Economics, forthcoming. 